\title{
Field Evaluation of Early and Late Leaf Spot Diseases in Advanced Breeding Lines of Groundnut (Arachis hypogaea L.)
}

\author{
Sajjan Kumar Pooniya, Sunil Yadav, Madhurjit Singh Rathore, \\ Sushma Tiwari", R. S. Sikarwar and M. K. Tripathi
}

\author{
College of Agriculture, Rajmata Vijayaraje Scindia Krishi Vishwavidyalaya, Gwalior \\ (Madhya Pradesh), India
}

*Corresponding author

\section{A B S T R A C T}

\begin{tabular}{|l|}
\hline K e y w o r d s \\
Advance backcross \\
Lines, Dendrogram, \\
$\begin{array}{l}\text { Early Leaf Spot, } \\
\text { Groundnut, Late } \\
\text { Leaf Spots, PCoA }\end{array}$ \\
\hline Article Info \\
\hline $\begin{array}{l}\text { Accepted: } \\
\text { 22 June } 2020 \\
\text { Available Online: } \\
\text { 10 July } 2020\end{array}$ \\
\hline
\end{tabular}

Leaf spots are the most serious foliar fungal diseases of groundnut (Arachis hypogaea L.) World wide. Early leaf spot and late leaf spots, singly or together can cause losses in pod yield of over $50 \%$ and reduce the quality of the pod and fodder. Screening of genotypes and advance breeding lines is one of the primary objective for resistance breeding in groundnut. Present investigation was carried out to screen 33 advance breeding lines and 7 released varieties of groundnut against early and late leaf spot diseases. Early leaf spot disease scoring was done at 35 and 45 days after sowing and late leaf spot scoring was done at 75 and 85 days after sowing on 1 to 9 scale. Dendrogram were constructed based on disease scoring data of both the diseases. Score 1-3 (0 to 20\% disease) was given to highly resistance lines, 4-5 for moderately resistance (21 to 50\%), 6-7 for susceptible (51 to $70 \%$ ) and $8-9$ for highly susceptible (71 to $100 \%$ ) lines. For early leaf spot 13 highly resistant, 8 moderately resistant, 4 Susceptible and 15 highly susceptible lines were identified. For late leaf spot 13 highly resistant, 7 moderately resistant, 3 susceptible and 16 highly susceptible lines were identified. Total 12 highly resistant lines having resistant to both i.e., early and late leaf spot diseases were identified. Identified resistant lines can be used as source of resistance and for hybridization programme to develop new resistant variety.

\section{Introduction}

Groundnut (Arachis hypogaea L. $2 \mathrm{n}=40$ ) is an important legume crop rich in oil, protein, vitamins and other micronutrients (Settaluri et al., 2012). It is grown nearly in 114 tropical and subtropical countries, covering area of 26.5 million ha with total production of 43.9 million tons and productivity of $1654 \mathrm{~kg} / \mathrm{ha}$ in 2014 (FAO, 2017). India ranks second in groundnut production after China, followed by USA and Nigeria. In India, it is cultivated on about 3.7 million ha with the production and productivity of 6.7 million tons and 1810 $\mathrm{kg} / \mathrm{ha}$ respectively during 2015-16 (Anonymous, 2017). Groundnut production is largely affected by multiple biotic and abiotic stresses, of which the two foliar fungal diseases, early leaf spot (ELS) caused by Passalora arachidicola (Hori) U. Braun 
(syn. Cercospora arachidicola) and late leaf spot (LLS) caused by Nothopassalora personata (Berk. \& M.A. Curtis) U. Braun, C. Nakash., Videira \& Crous (syn. Cercosporidium personatum), are most important. Both fungal diseases produce lesions (up to $1 \mathrm{~cm}$ in diameter) on groundnut leaves, stems, petioles, and pegs (McDonald et al., 1985, Subrahmanyam et al., 1989). Leaf spots damage the plant by reducing the available photosynthetic area, lesion formation, and by stimulating leaflet abscission. Shedding of infected leaves upon disease progression can lead to complete defoliation in susceptible genotypes (Singh $e t$ al., 2011). Figure 1 shows severe damage to groundnut crops caused by early and late leaf spot in the Gwalior, Madhya Pradesh, India. Worldwide, yield losses range from $10 \%$ to over $50 \%$, but vary considerably from place to place and between seasons. Yield losses are generally substantial upto $70 \%$ when the crop is attacked by both leaf spots and rust. The cultivation of resistant and tolerant groundnut varieties does not only eliminate the crop losses caused by disease, it also contributes to reduce costs related to fungicide sprayings and other control methods. Identification of resistant sources and knowledge of components and mechanism of resistance are the pre-requisite for the success of disease resistance breeding programs. Insufficient disease incidence also complicates the selection of resistant plants in field experiments (Tshilenge et al., 2012, Mondal et al., 2014, Pramanik et al., 2019). Chaudhary et al., (2019) used a set of 340 diverse peanut genotypes and screened for LLS and rust resistance and yield traits across three locations in India under natural and artificial disease epiphytotic conditions. The study revealed significant variation among the genotypes for LLS and rust resistance at different environments. Recently, Chu et al (2019) developed an RIL population from crossing Florida-07 $\times$ GP-NC WS 16 and utilized this population to map QTLs associated with ELS and LLS resistance. Screening and identification of germplasm and advance breeding lines for foliar fungal diseases is one of the primary objective for resistant breeding. The present investigation was conducted for screening of foliar fungal disease early leaf spot and late leaf spot disease in groundnut at field conditions. This study reports the screened disease resistance genotypes at filed conditions these genotypes can be used in breeding programme and development new variety of groundnut and application of resistance genotypes used in marker assisted selection for further rustresistant breeding programs in groundnut.

\section{Materials and Methods}

Total thirty three advance breeding lines of groundnut received from ICRISAT and six popular genotypes i.e., KDG-128 TG-26 GANGAPURI SUNOLIC 95-R ICGS-44 JGN-3 GPBD-4 were screened for leaf spot diseases during Kharif seasons 2019. Genotypes were grown in RBD with three replications at KVK, Research Farm, College of Agriculture, RVSKVV, Gwalior, Madhya Pradesh. Scoring for diseases was done at 35 and 45 days for early leaf spot and at 75 and 85 days for late leaf spot. Disease scoring was based on 1-9 scale visual score indicated as $1=$ highly resistance $0 \%, 1-3=$ resistance 1 $20 \%, 4-5=$ moderate resistance $21-50 \%, 6-7=$ susceptible $51-70 \%$ and $8-9=$ highly susceptible 70-100\% (ICRISAT, 1995) (Table 1). Dendrogram was constructed and Principal coordinates analysis was done using Darwin software 6.0.21 versions.

\section{Results and Discussion}

\section{Early Leaf Spots Disease (ELS)}

Disease scoring data for early leaf spots (ELS) was analyzed using Darwin software 
and constructed dendrogram showed different groups of the groundnut genotypes (Table $1 \&$ Table 2). Cluster analysis revealed that genotypes of groundnut under study divided into two groups' major group I and minor Groups II (Fig 2). Major group I contained 21 genotypes divided into two subs grouped "A" and "B". Sub grouped "A" contained 13 genotypes were resistant as they were having disease score 1-3 (0-20\%) including, ABL-22, ABL-23, ABL-18, ABL-24, ABL-17, ABL15, ABL-29, ABL-33, ABL-20, ABL-19, ABL-30, ABL-21, Sunolic-95R (Table 2). Sub grouped "B" contained 8 genotypes namely ABL-13, ABL-9, ABL-2, ABL-16, ABL-5, Gangapuri, ICGS-44, and ABL-1 showing moderate resistance against the early leaf spot disease having disease score was 4-5 (21-50\%). Groups II divided into two sub groups "C" and "D" sub grouped " $\mathrm{C}$ " contained 4 genotypes i.e., ABL-31, ABL-27, GPBD-4 and KDG-4 showing susceptible lines (51-70\%) and disease score was 6-7. Sub groups " $D$ " contains 15 genotypes namely ABL-14, ABL-25, ABL-28, ABL-8, ABL-11, ABL-32, ABL-3, ABL-4, ABL-10, ABL-6, ABL-26, ABL-12, ABL-7, JGN-3 and TG-26 were highly susceptible (70$100 \%$ ) and disease score was 8-9.

\section{Late Leaf Spots Disease (LLS)}

Characterization of advance breeding lines of groundnut was done for late leaf spot (LLS) at 75 and 85 days after sowing and data were analyzed using Darwin software and a dendrogram was constructed. Cluster analysis constructed different group on the basis of disease score data 1-9 scale. In dendrogram two groups i.e., I (major) and II (minor) were formed (Fig 3). Major group I consisted 13 genotypes i.e., ABL-22, ABL-23, ABL-18, ABL-24, ABL-17, ABL-15, ABL-29, ABL33, ABL-20, ABL-19, ABL-30, ABL-21 and ABL-16 having disease score 1-3 showed resistance $(0-20 \%)$ against the late leaf spot disease. Groups II divided into two sub groups "A" and "B". Sub grouped "A" contained 19 genotypes and sub grouped "B" contained 8 genotypes. Sub grouped "A" further divided into two sub grouped " $C$ " and "D". Sub grouped "C" contained 16 genotypes namely ABL-14, ABL-11, GPBD4, ABL-28, JGN-3, ABL-25, TG-26, ABL-32, ABL-3, ABL-4, ABL-10, ABL-6, ABL-8, ABL-7, ABL-12 and ABL-26 were highly susceptible (70-100\%) and disease score was 8-9. Sub grouped "D" contained 3 genotypes i.e., ABL-31, ABL-27 and KDG-128 with disease susceptible (51-70\%) and sub grouped "B" contained 7 genotypes i.e., ABL-5, ABL1, ABL-2, ABL-13, ICGS-44, SUNOLIC 95$\mathrm{R}$, and Gangapuri showed moderately resistance against late leaf spots disease (Table $1 \& 3$ ).

\section{Principal coordinates analysis (PCoA)}

\section{Early Leaf Spots}

Principal coordinates analysis (PCoA) is a member of the factorial analysis family working on distance matrices. Factorial analysis methods constitute two very different approaches for the representation of data structure. Principal coordinates analysis (PCoA) of groundnut genotypes showed relationship of early leaf spots disease resistant. According to PCoA of present study, 13 genotypes were grouped together namely ABL-22, ABL-23, ABL-18, ABL-24, ABL-17, ABL-15, ABL-29, ABL-33, ABL20, ABL-19, ABL-30, ABL-21, and Sunolic95R showing resistance, 8 genotypes namely ABL-13, ABL-9, ABL-2, ABL-16, ABL-5, Gangapuri, ICGS-44, ABL-1 showed moderate resistant, 4 genotypes ABL-31, ABL-27, GPBD-4 and KDG-4 grouped together showing susceptible, while ABL-14, ABL-25, ABL-28, ABL-8, ABL-11, ABL-32, ABL-3, ABL-4, ABL-10, ABL-6, ABL-26, ABL-12, ABL-7, JGN-3 and TG-26 found highly susceptible against early leaf spots (Fig 4). 
Principal coordinates analysis (PCoA)

\section{Late Leaf Spots}

Principal coordinates analysis (PCoA) of groundnut genotypes for late leaf spot grouped resistant $(0-20 \%)$ lines including ABL-22, ABL-23, ABL-18, ABL-24, ABL17, ABL-15, ABL-29, ABL-33, ABL-20, ABL-19, ABL-30, ABL-21 and ABL-16. Seven groundnut genotypes i.e., ABL-5, ABL-1, ABL-2, ABL-13, ICGS-44, SUNOLIC 95-R, and Gangapuri showed moderate resistant (21-50\%), ABL-31, ABL27 and KDG-1 showed susceptible (51-70\%), while ABL-14, ABL-11, GPBD-4, ABL-28,
JGN-3，ABL-25，TG-26，ABL-32，ABL-3, ABL-4, ABL-10, ABL-6, ABL-8, ABL-7, ABL-12 and ABL-26 showed highly susceptible (70-100\%) pattern for late leaf spot.

For early leaf spot 13 highly resistant, 8 moderately resistant, 4 Susceptible and 15 highly susceptible lines were identified. For late leaf spot 13 highly resistant, 7 moderately resistant, 3 susceptible and 16 highly susceptible lines were identified. Total 12 highly resistant lines having resistant to both i.e., early and late leaf spot diseases were identified.

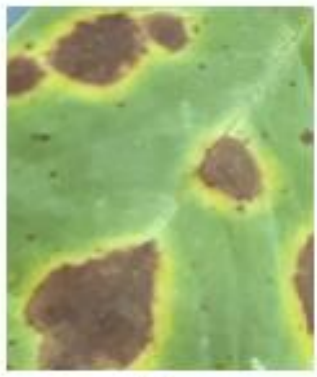

B

A and B showed early leaf spot (ELS) disease symptoms brown lesions usually surrounded by yellow color on the upper side the leaves

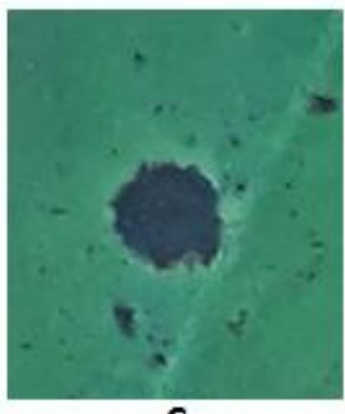

C

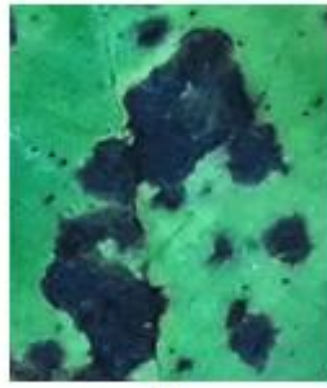

D

$\mathrm{C}$ and D showed late leaf spot (LLS) disease symptoms circular and darker spots appear on lower surface the leaves

Figure.1 Disease symptoms of early leaf spot (ELS) and late leaf spot (LLS) in advance breeding lines of groundnut 


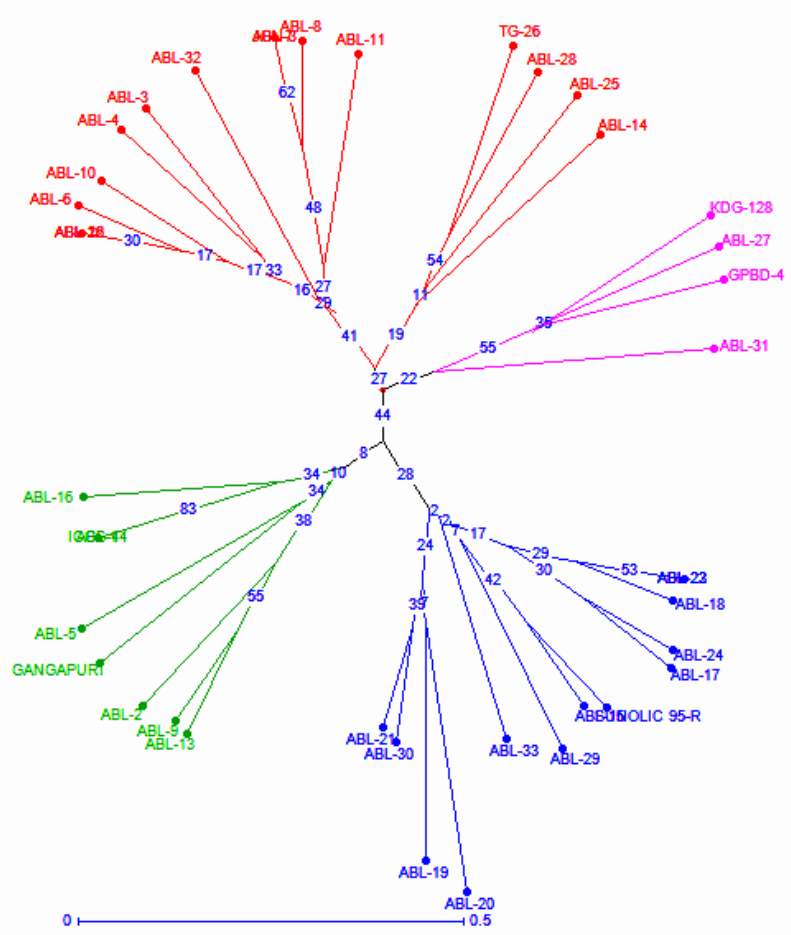

Fig.2 Dendrogram show disease relationship of early leaf spot disease resistance in 40 groundnut (Arachis hypogaea L) germplasm

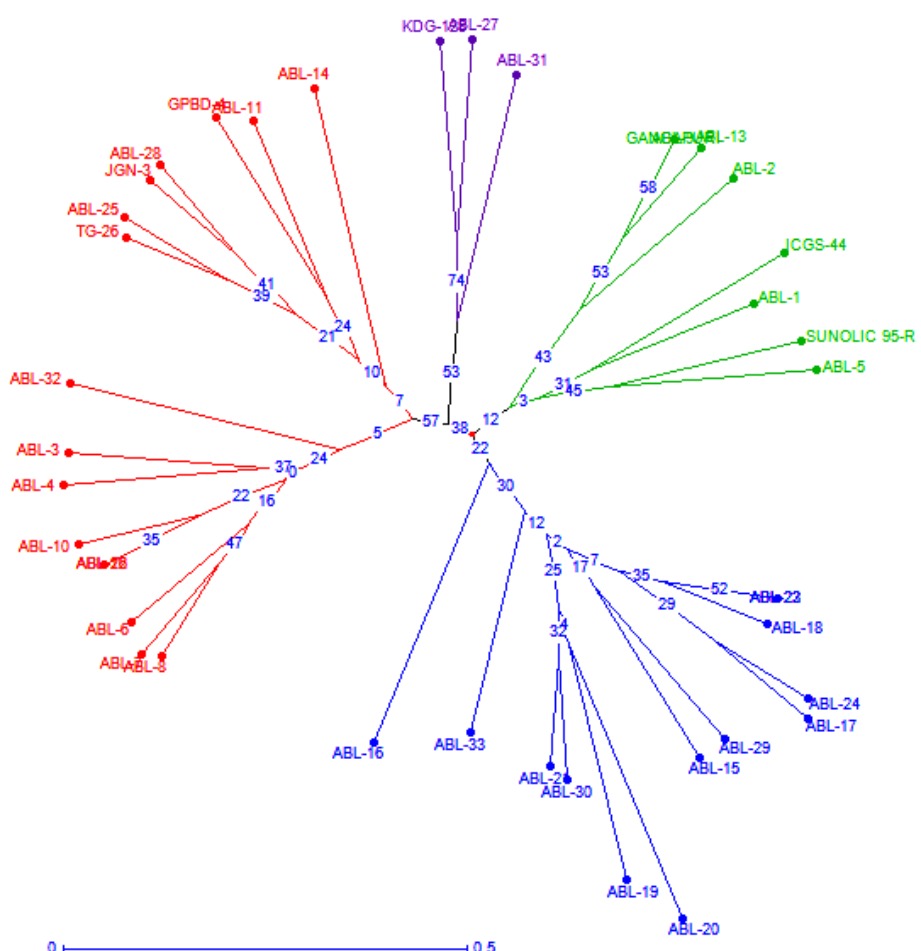

Fig.3 Dendrogram show disease relationship of late leaf spot disease resistance in 40 groundnut (Arachis hypogaea L) germplasm 


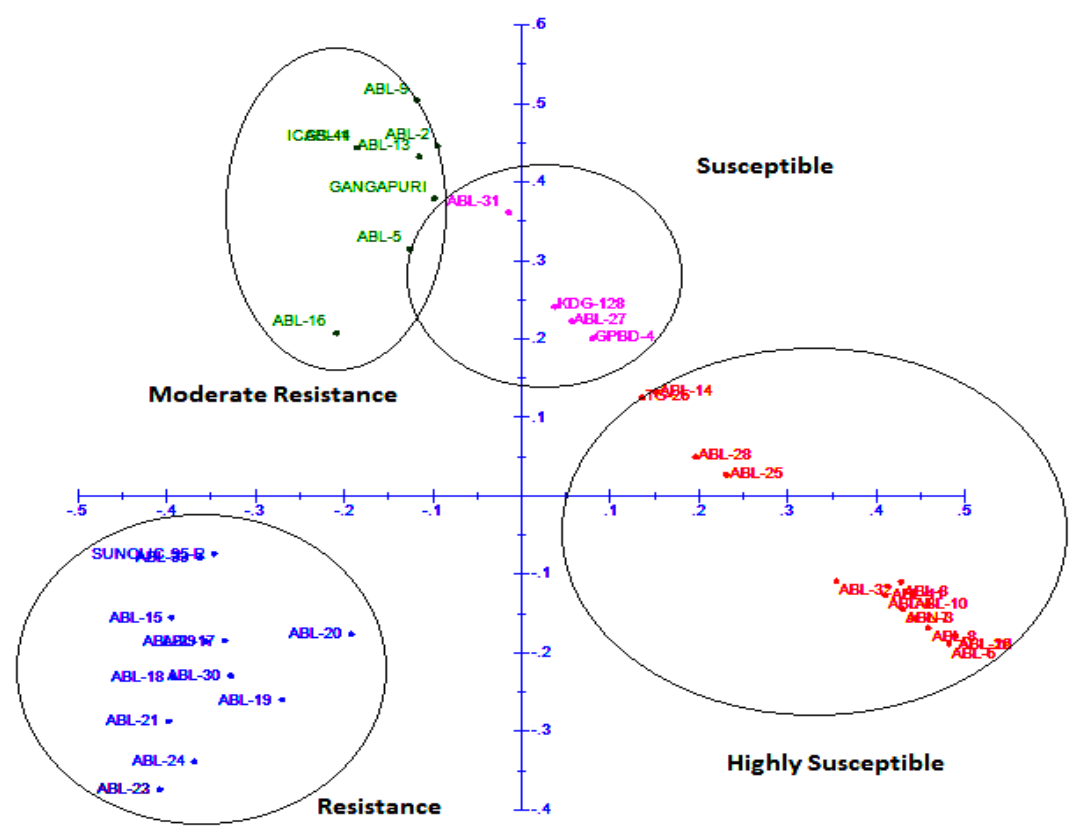

Fig.4 Principal coordinates analysis (PCoA) early leaf spots disease relationship 40 groundnut genotypes

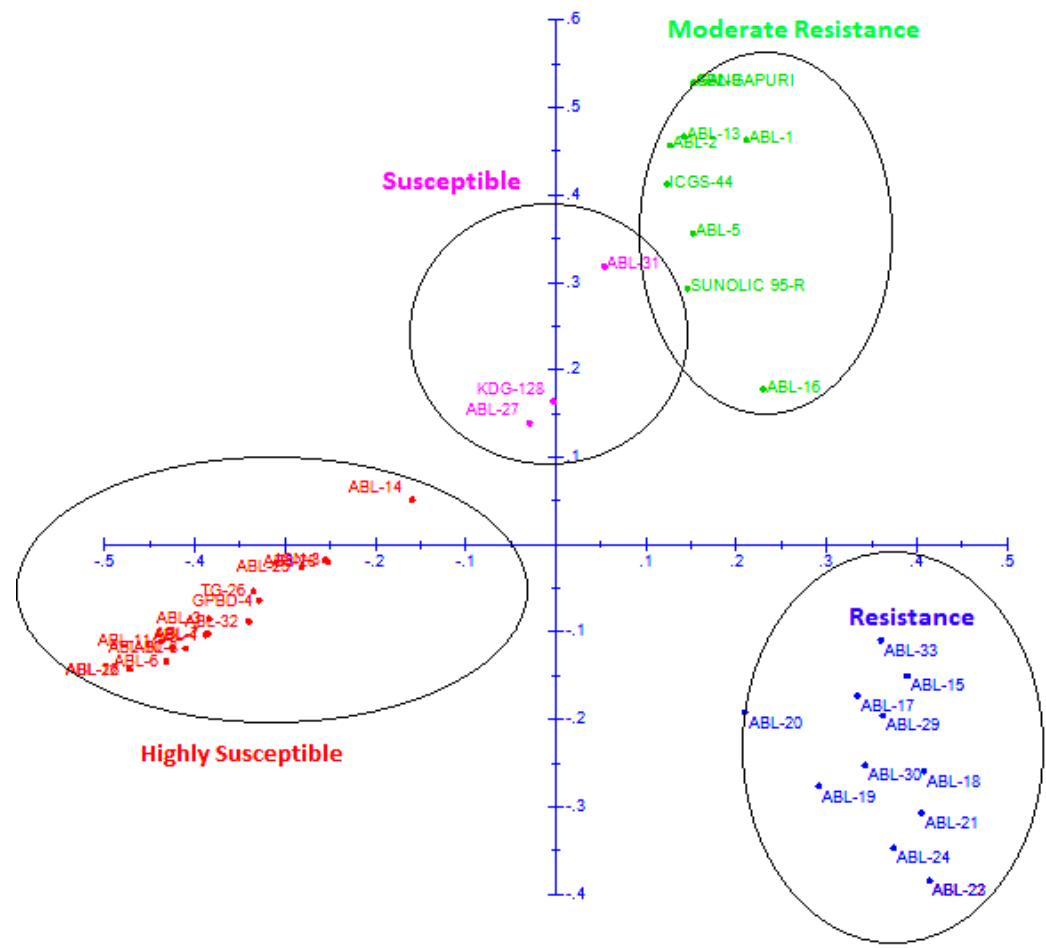

Fig.5 Principal coordinates analysis (PCoA) late leaf spots disease relationship 40 groundnut genotypes 
Table 1. Disease scoring for early leaf spot and late leaf spot data of groundnut at different time intervals

\begin{tabular}{|c|c|c|c|c|c|c|c|c|c|c|c|c|c|}
\hline \multirow{3}{*}{ S.No. } & \multirow{3}{*}{$\begin{array}{l}\text { Name of } \\
\text { Genotypes }\end{array}$} & \multicolumn{6}{|c|}{ Disease score for early leaf spots (ELS) } & \multicolumn{6}{|c|}{ Disease score for late leaf spots (LLS) } \\
\hline & & \multicolumn{3}{|c|}{30 DAS } & \multicolumn{3}{|c|}{45 DAS } & \multicolumn{3}{|c|}{75 DAS } & \multicolumn{3}{|c|}{85 DAS } \\
\hline & & $\mathbf{R}_{1}$ & $\mathbf{R}_{2}$ & $\mathbf{R}_{\mathbf{3}}$ & $\mathbf{R}_{1}$ & $\mathbf{R}_{2}$ & $\mathbf{R}_{\mathbf{3}}$ & $\mathbf{R}_{1}$ & $\mathbf{R}_{2}$ & $\mathbf{R}_{\mathbf{3}}$ & $\mathbf{R}_{1}$ & $\mathbf{R}_{2}$ & $\mathbf{R}_{\mathbf{3}}$ \\
\hline 1 & ABL-1 & 4 & 3 & 4 & 3 & 3 & 3 & 5 & 4 & 4 & 5 & 4 & 4 \\
\hline 2 & ABL-2 & 5 & 5 & 6 & 5 & 4 & 4 & 6 & 6 & 5 & 5 & 4 & 4 \\
\hline 3 & ABL-3 & 8 & 8 & 9 & 7 & 8 & 7 & 8 & 7 & 8 & 9 & 9 & 9 \\
\hline 4 & ABL-4 & 8 & 9 & 9 & 8 & 8 & 9 & 9 & 8 & 8 & 9 & 9 & 9 \\
\hline 5 & ABL-5 & 4 & 5 & 5 & 4 & 4 & 4 & 5 & 4 & 6 & 6 & 5 & 4 \\
\hline 6 & ABL-6 & 8 & 8 & 9 & 8 & 9 & 9 & 8 & 9 & 9 & 9 & 9 & 9 \\
\hline 7 & ABL-7 & 7 & 7 & 8 & 8 & 7 & 7 & 8 & 9 & 8 & 9 & 9 & 8 \\
\hline 8 & ABL-8 & 6 & 7 & 8 & 8 & 7 & 8 & 8 & 9 & 9 & 9 & 9 & 8 \\
\hline 9 & ABL-9 & 5 & 6 & 5 & 4 & 4 & 4 & 5 & 6 & 6 & 5 & 4 & 4 \\
\hline 10 & ABL-10 & 7 & 7 & 7 & 6 & 6 & 6 & 7 & 8 & 9 & 9 & 9 & 9 \\
\hline 11 & ABL-11 & 8 & 7 & 8 & 7 & 8 & 7 & 8 & 8 & 9 & 8 & 9 & 8 \\
\hline 12 & ABL-12 & 8 & 9 & 9 & 9 & 9 & 9 & 8 & 8 & 9 & 9 & 9 & 9 \\
\hline 13 & ABL-13 & 6 & 5 & 5 & 4 & 4 & 4 & 4 & 6 & 6 & 5 & 4 & 4 \\
\hline 14 & ABL-14 & 7 & 6 & 6 & 5 & 5 & 6 & 7 & 7 & 7 & 8 & 8 & 8 \\
\hline 15 & ABL-15 & 3 & 3 & 4 & 3 & 3 & 3 & 3 & 4 & 3 & 3 & 3 & 4 \\
\hline 16 & ABL-16 & 6 & 5 & 5 & 4 & 4 & 4 & 5 & 4 & 4 & 4 & 4 & 3 \\
\hline 17 & ABL-17 & 3 & 2 & 2 & 2 & 2 & 2 & 2 & 3 & 3 & 3 & 3 & 4 \\
\hline 18 & ABL-18 & 5 & 4 & 4 & 3 & 3 & 3 & 3 & 3 & 3 & 3 & 4 & 3 \\
\hline 19 & ABL-19 & 3 & 3 & 3 & 3 & 2 & 3 & 2 & 3 & 3 & 2 & 2 & 3 \\
\hline 20 & ABL-20 & 4 & 3 & 3 & 3 & 3 & 3 & 3 & 2 & 3 & 2 & 2 & 2 \\
\hline 21 & ABL-21 & 3 & 4 & 3 & 2 & 2 & 3 & 3 & 4 & 3 & 3 & 2 & 3 \\
\hline 22 & ABL-22 & 3 & 2 & 2 & 2 & 2 & 2 & 3 & 3 & 3 & 3 & 3 & 3 \\
\hline 23 & ABL-23 & 4 & 3 & 3 & 2 & 3 & 3 & 3 & 3 & 3 & 3 & 3 & 3 \\
\hline 24 & ABL-24 & 3 & 3 & 2 & 2 & 2 & 2 & 2 & 3 & 3 & 3 & 3 & 3 \\
\hline 25 & ABL-25 & 7 & 8 & 7 & 7 & 6 & 6 & 7 & 8 & 8 & 8 & 7 & 8 \\
\hline 26 & ABL-26 & 7 & 8 & 7 & 7 & 7 & 7 & 8 & 8 & 9 & 9 & 9 & 9 \\
\hline 27 & ABL-27 & 7 & 6 & 6 & 6 & 6 & 6 & 6 & 7 & 7 & 7 & 7 & 6 \\
\hline 28 & ABL-28 & 7 & 6 & 7 & 7 & 6 & 7 & 7 & 8 & 8 & 8 & 8 & 7 \\
\hline 29 & ABL-29 & 3 & 4 & 3 & 3 & 2 & 3 & 3 & 4 & 4 & 3 & 3 & 3 \\
\hline 30 & ABL-30 & 3 & 3 & 3 & 3 & 2 & 2 & 3 & 4 & 3 & 2 & 2 & 3 \\
\hline 31 & ABL-31 & 6 & 5 & 5 & 4 & 4 & 5 & 6 & 7 & 7 & 5 & 4 & 5 \\
\hline 32 & ABL-32 & 8 & 9 & 8 & 9 & 9 & 9 & 9 & 9 & 9 & 8 & 9 & 9 \\
\hline 33 & ABL-33 & 4 & 5 & 4 & 3 & 3 & 3 & 4 & 4 & 3 & 3 & 4 & 3 \\
\hline 34 & KDG-128 & 6 & 7 & 6 & 7 & 6 & 6 & 6 & 7 & 7 & 6 & 6 & 6 \\
\hline 35 & TG-26 & 7 & 8 & 7 & 7 & 8 & 7 & 8 & 8 & 8 & 8 & 7 & 8 \\
\hline 36 & GANGAPURI & 5 & 5 & 5 & 6 & 4 & 4 & 5 & 6 & 6 & 5 & 4 & 4 \\
\hline 37 & SUNOLIC 95-R & 4 & 4 & 3 & 3 & 3 & 4 & 6 & 4 & 4 & 6 & 5 & 4 \\
\hline 38 & ICGS-44 & 5 & 4 & 4 & 5 & 4 & 4 & 5 & 5 & 4 & 5 & 5 & 4 \\
\hline 39 & JGN-3 & 8 & 9 & 8 & 9 & 9 & 8 & 7 & 8 & 8 & 8 & 7 & 7 \\
\hline 40 & GPBD-4 & 7 & 7 & 7 & 7 & 6 & 6 & 8 & 8 & 9 & 8 & 8 & 7 \\
\hline
\end{tabular}


Table.2 Early leaf spots disease characterization of groundnut genotypes

\begin{tabular}{|c|c|c|}
\hline S.No. & Name of Category & Name of Genotype \\
\hline 1 & $\begin{array}{l}\text { Highly Resistance } \\
(0 \%)\end{array}$ & $\begin{array}{l}\text { ABL-22, ABL-23, ABL-18, ABL-24, ABL-17, ABL-15, } \\
\text { ABL-29, ABL-33, ABL-20, ABL-19, ABL-30, ABL-21, } \\
\text { Sunolic-95R. }\end{array}$ \\
\hline 2 & $\begin{array}{l}\text { Moderate Resistance } \\
(21-50 \%)\end{array}$ & $\begin{array}{l}\text { ABL-13, ABL-9, ABL-2, ABL-16, ABL-5, Gangapuri, } \\
\text { ICGS-44, ABL-1 }\end{array}$ \\
\hline 3 & $\begin{array}{l}\text { Susceptible } \\
(50-70) \%\end{array}$ & ABL-31, ABL-27, GPBD-4, KDG-4 \\
\hline 4 & $\begin{array}{l}\text { Highly Susceptible } \\
(70-100 \%)\end{array}$ & $\begin{array}{l}\text { ABL-14, ABL-25, ABL-28, ABL-8, ABL-11, ABL-32, } \\
\text { ABL-3, ABL-4, ABL-10, ABL-6, ABL-26, ABL-12, ABL-7, } \\
\text { JGN-3 TG-26 }\end{array}$ \\
\hline
\end{tabular}

Table.3 Late leaf spots disease characterization of 40 groundnut genotypes

\begin{tabular}{|c|c|c|}
\hline S.No. & Name of Category & Name of Genotype \\
\hline 1 & $\begin{array}{l}\text { Highly Resistance } \\
(0 \%)\end{array}$ & $\begin{array}{l}\text { ABL-22, ABL-23, ABL-18, ABL-24, ABL-17, ABL-15, } \\
\text { ABL-29, ABL-33, ABL-20, ABL-19, ABL-30, ABL-21 } \\
\text { and ABL-16 }\end{array}$ \\
\hline 2 & $\begin{array}{l}\text { Moderate Resistance } \\
(21-50 \%)\end{array}$ & $\begin{array}{l}\text { ABL-5, ABL-1, ABL-2, ABL-13, ICGS-44, SUNOLIC } \\
\text { 95-R, Gangapuri }\end{array}$ \\
\hline 3 & $\begin{array}{l}\text { Susceptible } \\
(50-70) \%\end{array}$ & ABL-31, ABL-27, KDG-128 \\
\hline 4 & $\begin{array}{l}\text { Highly Susceptible } \\
(70-100 \%)\end{array}$ & $\begin{array}{l}\text { BL-14, ABL-11, GPBD-4, ABL-28, JGN-3, ABL-25, } \\
\text { TG-26, ABL-32, ABL-3, ABL-4, ABL-10, ABL-6, ABL- } \\
\text { 8, ABL-7, ABL-12 and ABL-26 }\end{array}$ \\
\hline
\end{tabular}

Although early and LLS diseases occur naturally in all the peanut growing areas, the disease epidemic and severity is influenced by the history of leaf spot incidence, crop rotation and fungicide application (Fulmer, 2017). Early leaf spots are brown to reddish brown in color and always have yellow spots. Late leaves spots are characterized by dark brown to black spots and usually do not have yellow spots. When the condition is favorable for infection, leaf spot lesions begin to appear within 3-5 weeks after planting for ELS and about 1 month later for LLS. Since it only takes 10 to 15 days for the newly emerged lesions to sporulate, both diseases can go through many cycles of reproduction before harvest; therefore, with no fungicide applications, both leaf spot diseases can result in severe pod yield loss. In this study, the field evaluation was conducted without fungicide applications, which created environmental conditions, highly favorable to disease incident. Chu et al., (2019) also did screening for ELS and LLS and the field evaluation was conducted without fungicide applications and reported a SNP-based genetic map, consistent QTLs for resistance to ELS and LLS diseases were identified on chromosomes 3 and 5, respectively. Both ELS and LLS agents have the ability to over winter in the soil where the conidia are deposited on the debris of plant tissue. Beginning around mid-season, the pathogens progressively encroach upon peanut plants starting from the leaves closest to the ground and migrating to the upper layers of the canopy. If fungicides are not applied after the appearance of symptoms, both ELS and LLS will cause 
defoliation toward the later stages of disease progression. Day et al., (2016) conducted an experiments to investigate the effect of date of sowing on groundnut cultivars against late leaf spot disease severity, defoliation, frequency and size of the leaf spot which revealed that all these aspects were significantly influenced by the date of sowing and crop varieties which directly affect the pod yield and test weight.

Present study investigation was screening of genotypes against early and late leaf spot in groundnut based on 1-9 disease score in field condition. Groundnut yield is constrained mainly due to two major foliar fungal diseases as early leaf spots and late leaf spot disease affects not only seed yield but also fodder yield and quality. These diseases cause yield loss up to $70 \%$ in the crop (Subrahmanyam et al., 1985) and development of resistant cultivars is one of the best means of reducing crop yield losses from late leaf spot and also the best strategy to overcome additional cost of production (Prabhu et al., 2015). The obtained results reported early leaf spots resistant lines i.e., ABL-22, ABL-23, ABL18, ABL-24, ABL-17, ABL-15, ABL-29, ABL-33, ABL-20, ABL-19, ABL-30, ABL21, Sunolic-95R and late leaf spots resistant genotypes i.e., ABL-22, ABL-23, ABL-18, ABL-24, ABL-17, ABL-15, ABL-29, ABL33, ABL-20, ABL-19, ABL-30, ABL-21 and ABL-16. Further marker assisted selection will be applied for selection of resistant lines. These selected resistant lines may be used as a gene pool to obtain superior commercial types and to improve early and late leaf spot resistance in groundnut.

\section{Acknowledgment}

Authors are thankful to $\mathrm{Dr} \mathrm{P}$ Janila, ICRISAT, Hyderabad for providing advance breeding lines of groundnut and the financial support received from MPCST Bhopal,
Madhya Pradesh for conducting research work.

Conflict of interest: Authors have declared no conflict of interest

\section{References}

Anonymous (2017) Directorate of Economics \& Statistics, Department of Agriculture, Cooperation\& Farmers Welfare.

Chaudhari S, Khare D, Patil S C, Sundravadana S, Murali T V, Sudini H $\mathrm{K}$, Manohar S S, Bhat R S and Pasupuleti J (2019) Genotype $\times$ Environment Studies on Resistance to Late Leaf Spot and Rust in Genomic Selection Training Population of Peanut (Arachis hypogaea L.) Front. Plant Sci., doi.org/10.3389/fpls.2019.01338

Chu Y, Peng C P, Culbreath A, Isleib T G, Holbrook C C and Akins P O (2019) Major QTLs for Resistance to Early and Late Leaf Spot Diseases are Identified on Chromosomes 3 and 5 in Peanut (Arachis hypogaea). Front. Plant Sci. doi.org/10.3389/fpls.2019.00883

Dey U, Dhutraj D.N., Suryawanshi A.P., Bhattacharjee R and Talukdar D (2016) Response of groundnut (Arachis hypogaea L.) cultivars to late leaf spot disease (Passalora personata) under different sowing dates. Legume Research-An International Journal. 39: 1028-1033

FAOSTAT. (2017). Online Agriculture Statistics. http://www.fao.org/faostat/e n/\#data/QC.

Fulmer, A. M. (2017). Differentiation, Prediction and Management of Early and Late Leaf Spot of Peanut in the Southeastern United States and Haiti. Ph. D, the University of Georgia, 
Georgia.

McDonald, D., Subrahmanyam, P., Gibbons, R. W., and Smith, D. H. (1985). Early and Late Leaf Spots of Groundnut. Patancheru: ICRISAT Information Bulletin.

Mondal S., and Badigannavar AM (2014). Molecular diversity and association of SSR markers to rust and late leaf spot resistance in cultivated groundnut (Arachis hypogaea L.). Plant Breeding, 129: 68-71.

Pramanik A, Sushma Tiwari, M.K. Tripathi, R.S. Tomar and A. K. Singh. (2019) Molecular characterization of groundnut (Arachis hypogaea L.) germplasm lines for yield attributed traits. Indian J. Genet., 79(1): 56-65

Settaluri, V. S., Kandala, C. V. K., Puppala, N., and Sundaram, J. (2012). Peanuts and their nutritional aspects-a review. Food Nutr. Sci. 3, 1644-1650.

Singh, M. P., Erickson, J. E., Boote, K. J., Tillman, B. L., Jones, J. W., and van Bruggen, A. H. C. (2011). Late leaf spot effects on growth, photosynthesis, and yield in peanut cultivars of differing resistance. Agron. J. 103, 8591. doi: 10.2134/agronj2010.0322

Subrahmanyam P, Rao VR, Mcdonald D, Moss JP, Gibbons RW (1989) Origins of resistance to rust and late leaf spot in peanut (Arachis hypogaea Fabaceae). Econ Bot 43: 444-455

Tshilenge L. L., Nkongolo KK, Kalonji MA, and Kizungu RV (2012) Epidemiology of the Groundnut (Arachis hypogaea L.) Leaf Spot Disease: Genetic Analysis and Developmental Cycles. American Journal of Plant Sciences. 3: $582-588$

\section{How to cite this article:}

Sajjan Kumar Pooniya, Sunil Yadav, Madhurjit Singh Rathore, Sushma Tiwari, R. S. Sikarwar and Tripathi, M. K. 2020. Field Evaluation of Early and Late Leaf Spot Diseases in Advanced Breeding Lines of Groundnut (Arachis hypogaea L.). Int.J.Curr.Microbiol.App.Sci. 9(07): 3910-3919. doi: https://doi.org/10.20546/ijcmas.2020.907.458 